\title{
EMPATI DAN MOTIVASI KERJA GURU SEKOLAH LUAR BIASA
}

\author{
Iriani Indri Hapsari* \\ $\operatorname{Mardiana}^{* *}$ \\ * Program Studi Psikologi, Universitas Negeri Jakarta \\ ** Program Studi Psikologi, Universitas Negeri Jakarta
}

DOI: https://doi.org/10.21009/JPPP.051.07

\author{
Alamat Korespondensi: \\ ririnanwar@unj.ac.id \\ dianaghozali@rocketmail.com
}

\begin{abstract}
This study aims to determine the effect of empathy on teachers work motivation in special needs school. The population of this study are the teachers of special needs school. This study uses a quantitative method with the sample amounted to 81 respondents. This study uses two scales which are the scale of teacher's work motivation and empathy scale. Both of the scale were arranged by researcher based on work motivation theories of Louis George and Tara Sabhapathy. Empathy scale based on empathy theories of The QCAE ( Questionnaire of Cognitive and Affective Empathy). The hypothesis test used in this study using a regression analysis one predictor. Based on the analysis of data, obtained F count $11.272>$ F Table 3.96 with $p=0.001$ $(p<0.05)$. Its means there is a significant influence of empathy on teacher's work motivation in special needs school. The result shows a positive influence which means if there's a high level of empathy in special need school's teachers, then the level of work motivation will be high.
\end{abstract}

\section{Keywords}

empathy, teacher's performance, school for disabled children

\section{Pendahuluan}

Pendidikan memiliki peranan penting bagi kehidupan bangsa. Pendidikan merupakan suatu pondasi penting yang harus dimiliki oleh setiap manusia, dengan tujuan untuk membentuk manusia yang berakhlak baik, berbudi pekerti luhur, dan tentunya adalah mencerdaskan kehidupan bangsa. Pendidikan harus mampu memberikan perubahan yang signifikan demi terciptanya pendidikan yang tersebar luas, merata, dan bermutu baik bagi kehidupan masyarakat.

Seperti yang dijelaskan dalam Undang- undang Republik Indonesia Nomor 20 tahun 2003 tentang Sistem Pendidikan Nasional pada pasal 1 ayat 1 tentang pengertian pendidikan, yaitu: "Pendidikan adalah usaha sadar dan terencana untuk mewu- judkan suasana belajar dan proses pembelajaran agar peserta didik secara aktif mengembangkan potensi dirinya untuk memiliki kekuatan spiritual keagamaan, pengendalian diri, kepribadian, kecerdasan akhlak mulia, serta keterampilan yang diperlukan dirinya, masyarakat, bangsa dan Negara."

Pendidikan merupakan hak segala warga Negara. Ini berarti pendidikan tidak boleh memandang suku, agama, ras, tingkat sosial, ekonomi, maupun fisik seseorang. Individu normal maupun yang memiliki keterbatasan fisik, mental, emosional, dan intelektual wajib untuk mendapatkan pendidikan yang layak. Untuk mereka yang memiliki keterbatasan tersebut bisa menempuh pendidikan khusus, salah satunya adalah di Sekolah Luar Biasa (SLB). Hal ini 
seperti yang telah disebutkan dalam UUD 1945 pasal 31 ayat 1 dan Undang-undang nomor 20 tahun 2003 tentang sistem pendidikan nasional, yang menyebutkan bahwa Negara memberikan jaminan penuh bagi anak berkebutuhan khusus (ABK) untuk memperoleh pendidikan yang bermutu.

SLB merupakan sarana pendidikan yang dibuat khusus untuk melayani dan mendidik para individu yang memiliki kebutuhan khusus atau yang biasa disebut dengan Anak Berkebutuhan Khusus (ABK). ABK memiliki karakteristik yang sangat berbeda jika dibandingkan dengan anak normal. ABK merupakan anak dengan karakteristik khusus yang berbeda dengan anak pada umumnya tanpa selalu menunjukkan pada ketidakmampuan mental, emosi, atau fisik.

Menurut Shanty (2012), anak yang termasuk ke dalam $\mathrm{ABK}$ antara lain: tuna netra, tuna rungu, tuna grahita, tuna daksa, tuna laras, kesulitan belajar, gangguan perilaku, anak berbakat, dan anak dengan gangguan kesehatan. Oleh karena itu ABK seperti anak pada umumnya yaitu membutuhkan pendidikan sesuai dengan kekhususannya masing-masing. SLB A untuk anak tuna netra, SLB B untuk anak tuna rungu, SLB C untuk anak tuna grahita, SLB D bagi anak tuna daksa dan SLB E bagi anak tuna laras.

Sama seperti sistem pada pendidikan untuk individu normal, guru merupakan salah satu faktor penting dalam pendidikan, mereka memiliki peran dalam proses belajar mengajar yang amat dominan. Oleh sebab itu guru adalah salah satu unsur di dalam pendidikan yang harus berperan aktif dan memiliki tanggung jawab untuk mendidik para siswa siswi mereka untuk mencapai taraf kematangan tertentu dalam segi ilmu pendidikan maupun dalam kehidupan bermasyarakat.

Menurut peraturan Kementerian Pendidikan dan Kebudayaan Nomor 16 Tahun 2007 mengenai Standar Kualifikasi Akademik dan Kompetensi guru menyebutkan bahwa seorang guru tidak hanya harus memiliki kompetensi pedagogi (ilmu pendidikan/pengajaran) dalam proses belajar mengajar, melainkan juga kompetensi kepribadian, kompetensi sosial, dan kompetensi profesional.

Menurut Uno (dalam Muzdalifah \& Listyasari, 2013) guru adalah orang dewasa yang secara sadar bertanggung jawab dalam mendidik, mengajar dan membimbing peserta didik. Dalam proses tersebut banyak hal yang harus dipahami dan dipersiapkan oleh seorang guru, karena setiap siswa memiliki karakteristik yang berbeda dan tidak dapat disamakan antara satu dengan yang lain. Tidak terkecuali pada anak berkebutuhan khusus (ABK).

Tugas guru untuk ABK tidaklah sama dengan guru pada anak normal. Beban yang harus ditempuh lebih berat, karena mereka harus berhadapan dengan anak yang memiliki kebutuhan khusus dengan karakteristik berbeda- beda. Oleh karena itu tugas yang dilakukan oleh guru SLB tidak hanya mengajar, tetapi mereka juga harus mengasuh dan membimbing para peserta didiknya dengan penanganan yang khusus.

Hal tersebut setara dengan pernyataan Rosdiana (dalam Widuri dan Firmansyah, 2014) bahwa menjadi guru SLB sangat berbeda dengan guru di sekolah umum, selain harus sabar dan juga tekun dalam menghadapi anak didiknya, mereka juga harus ikhlas dalam memberikan pelajaran, guru SLB harus menganggap anak didiknya sebagai anak sendiri dan ketika sedang mengajar harus mampu membaca apa yang diinginkan oleh anak didiknya.

Menurut Istiqomah (2015) guru ABK memiliki tanggung jawab khusus dalam menangani $\mathrm{ABK}$, karena ABK bukanlah anak yang mudah memahami pelajaran ataupun materi pelajaran secara cepat. Menurutnya untuk menjadi guru ABK salah satunya adalah latar belakang guru tersebut ingin menjadi guru ABK, karena untuk menjadi guru $\mathrm{ABK}$ bukan hanya keinginan saja yang diperlukan akan tetapi dibutuhkan motivasi dan alasan yang kuat. Mengajar ABK tidak semudah mengajarkan anak normal pada umumnya, maka dari itu dibutuhkan dorongan yang kuat dalam diri seorang guru $\mathrm{ABK}$.

Dalam proses memenuhi tugas, tanggung jawab, dan tuntutan kerja yang dimiliki oleh seorang guru $\mathrm{ABK}$, maka guru $\mathrm{ABK}$ tersebut harus memiliki motivasi kerja yang baik. Motivasi kerja pada guru memang tidak mempunyai tampak yang nyata, akan tetapi motivasi kerja tersebut dapat diwujudkan dalam suatu hasil dari pekerjaan yang dikerjakan. Maka dari itu perlu diperhatikan bahwa motivasi kerja sangat penting bagi seorang guru, terutama bagi guru yang memiliki 
tantangan besar untuk menangani anak yang memiliki kekhususan agar guru tersebut senantiasa bekerja dengan perasaan senang dan tidak terpaksa sehingga dapat menciptakan kualitas pendidikan bagi ABK yang bermutu baik.

Selain itu motivasi kerja pada guru berkaitan dengan hasil mengajar guru tersebut, tak jarang ditemukan guru yang kurang memiliki gairah dan motivasi dalam melakukan tugasnya yang akhirnya mengakibatkan kurang berhasilnya tujuan yang ingin dicapai. Pernyataan tersebut berkaitan dengan penelitian yang dilakukan oleh Rohadi (2008) yang menyatakan bahwa guru yang memiliki motivasi yang rendah memiliki dampak tidak melaksanakan kegiatan dengan baik, guru tidak menggunakan metode pembelajaran yang relevan, dan guru tidak melaksanakan kegiatan belajar mengajar secara rutin sehingga jika motivasi mengajar rendah sulit diharapkan produktivitas pelaksanaan pembelajaran tinggi.

Menurut Munandar (2001) motivasi adalah suatu proses dimana kebutuhan-kebutuhan mendorong seseorang untuk melakukan serangkaian kegiatan yang mengarah ke tercapainya tujuan tertentu. Dari pernyataan tersebut bisa dijelaskan bahwa motivasi kerja merupakan kebutuhan pokok seorang guru dalam melaksanakan tugasnya untuk mengajar, kebutuhan tersebut dimaksudkan agar seorang guru dapat mencapai tujuannya dan juga agar terciptanya kualitas pendidikan yang baik.

Meneliti motivasi kerja pada guru ABK adalah salah satu cara untuk mengetahui apa saja yang mempengaruhi hasil dari proses mengajar guru tersebut. Hal ini penting untuk mengurangi dampak negatif yang timbul seperti kinerja mengajar guru dan hasil belajar dari ABK. Karena guru yang memiliki motivasi mengajar yang tinggi akan mampu untuk mendidik dan membimbing para peserta didik untuk mencapai tujuan yang lebih baik. Sebaliknya jika guru memiliki motivasi mengajar yang rendah, maka mereka kurang mampu dalam membimbing para peserta didik tersebut untuk mencapai tujuan yang lebih baik.

Hal tersebut berkaitan dengan pengertian motivasi menurut Schunk, Pintrinch, dan Meece (2012) bahwa motivasi sebagai suatu proses diinisiasikannya dan dipertahankannya aktivitas yang diarahkan pada pencapaian tujuan. Aktivitas tersebut merupakan aktivitas mental maupun fisik, aktivitas tersebut dapat menurun karena adanya faktor kelelahan, kegagalan, kebosanan, emosi-emosi negatif lainnya, hambatan yang bersifat eksternal, dan masalah yang ditemui untuk mencapai tujuan (Muzdalifah \& Listyasari, 2013).

Motivasi kerja yang dimiliki seorang guru harus berorientasi pada tanggung jawab mereka sebagai seorang pengajar. Motivasi juga memiliki peranan sangat penting dalam mencapai hasil kerja yang baik dan juga efektif. Motivasi memengaruhi kinerja guru, sehingga guru yang memiliki target yang jelas dalam proses belajar mengajar maka ABK dapat mengaplikasikan ilmu yang diberikan oleh guru disekolah maupun di lingkungan masyarakat.

Motivasi tersebut berasal dari dalam diri sendiri (intrinsik) dan juga dari luar diri (ekstrinsik). Motivasi intrinsik adalah motivasi untuk melibatkan diri dalam suatu aktivitas karena nilai/manfaat aktivitas itu sendiri dan bersifat kontekstual, sementara motivasi ekstrinsik adalah motivasi untuk melibatkan diri dalam suatu aktivitas sebagai suatu cara untuk mencapai sebuah tujuan (Muzdalifah \& Listyasari, 2013). Untuk melakukan suatu pekerjaan secara aktif Uno (2016) menjelaskan bahwa motivasi intrinsik merupakan hal yang tak dapat diabaikan, hal tersebut antara lain kebanggaan terhadap dirinya yang dapat melakukan sesuatu yang belum tentu orang lain bisa kerjakan, kecintaan terhadap pekerjaan itu, atau pun minat yang besar terhadap pekerjaan yang dilakukan selama ini. Maka dari itu motivasi kerja tidak hanya bersumber dari motivasi ekstrinsik saja, melainkan intrinsik juga merupakan aspek yang penting bagi motivasi kerja.

Seperti yang dikatakan Sardiman (dalam Uno, 2016) bahwa motivasi dapat dipandang sebagai perubahan energi dalam diri seseorang yang ditandai dengan munculnya "feeling", dan didahului dengan tanggapan terhadap adanya tujuan. Dalam hal "feeling" atau adanya rasa, motivasi relavan dengan persoalan kejiwaan, afeksi, dan emosi yang dapat menentukan tingkah laku manusia. Oleh karena itu selain motivasi kerja, guru seharusnya memiliki "feeling" atau perasaan dalam menghadapi ABK. Perasaan tersebut merupakan perasaan empati menurut Danim (2015) yang bermakna kemampuan seseorang dalam hal merasakan emosi orang lain atau pribadi-pribadi di luar dirinya. 
Rasa empati dalam diri guru dapat membantu guru untuk meningkatkan motivasi mengajar, karena empati merupakan kemampuan yang dimiliki oleh setiap individu untuk merasakan, menghargai, dan mengerti tentang perasaan orang lain. Baron dan Byrne (2005) menyatakan bahwa empati merupakan kemampuan untuk merasakan keadaan emosional orang lain, merasa simpatik dan mencoba menyelesaikan masalah, dan mengambil perspektif orang lain (Asih \& Pratiwi, 2010).

Guru merupakan orang tua peserta didik di sekolah, perhatian dan bimbingan guru sangat diperlukan, apalagi bagi ABK yang memang memerlukan perhatian lebih dari seorang guru di sekolah. Baron (2005) mengatakan bahwa empati adalah mereka yang menolong ditemukan mempunyai empati lebih tinggi dari pada mereka yang tidak menolong, partisipan yang paling altruistik menggambarkan diri mereka sebagai bertanggung jawab, bersosialisasi, menegangkan, toleran, memiliki self-control, dan termotivasi untuk membuat impresi yang baik.

Empati dalam kaitannya dengan guru SLB menurut peneliti dapat memiliki pengaruh terhadap motivasi kerja guru. Ketika guru SLB tidak memiliki perasaan empati terhadap anak didiknya (ABK), ini akan memberi dampak pada motivasi guru dalam mengajar. ABK bukanlah seperti anak normal yang bisa mengatakan apa yang sedang ia rasakan kepada guru mereka, dan ketika guru tidak merasakan apa yang sedang anak didiknya rasakan maka proses belajar tidak akan berjalan dengan lancar, maka dari itu diperlukan perasaan empati dalam guru ABK agar motivasi mengajar guru tersebut baik sehingga mendapatkan hasil pembelajaran yang juga baik. Karena empati berhubungan dengan banyak hal, seperti pikiran, kepercayaan, dan keinginan seseorang berhubungan dengan perasaannya, seseorang yang memiliki perasaan empati maka ia akan mampu mengetahui pikiran dan keadaan jiwa atau suasana hati (mood) orang lain (Danim, 2015). Dengan itu guru yang memiliki perasaan empati terhadap para peserta didiknya akan memiliki motivasi kerja yang baik karena guru tersebut telah mengerti dan memahami keadaan perserta didiknya, sehingga ia lebih mudah dalam mengajar dan mendidik ABK.
Berdasarkan dari penjelasan tersebut maka dapat disimpulkan bahwa perasaan empati dapat berpengaruh penting pada motivasi kerja guru SLB. Motivasi mengajar yang tinggi pada guru SLB dapat membantu guru tersebut dalam menghadapi dan mendidik para $\mathrm{ABK}$ agar menjadi pribadi yang baik dan juga dapat menciptakan pendidikan bagi ABK yang berkualitas. Untuk menunjang motivasi mengajar pada guru SLB maka perasaan empati diperlukan agar guru tersebut mudah dalam mengajar, mendidik, dan menghadapi ABK sehingga kinerja yang dihasilkan baik. Dengan demikian peneliti berencana akan melakukan penelitian mengenai Pengaruh Empati Terhadap Tinggi Motivasi Kerja Guru Pada Guru Sekolah Luar Biasa.

\section{Metode Penelitian}

Penelitian ini menggunakan metode kuantitatif atau yang juga disebut dengan metode tradisional. Menurut Sugiyono (2011) dikatakan bahwa metode kuantitatif disebut dengan metode positivistik karena berlandaskan pada filsafat positivisme, metode ini dikatakan sebagai metode kuantitatif karena data penelitian berupa angkaangka dan analisis menggunakan statistik. Pelaksanaan penelitian ini menggunakan metode kuesioner, dengan cara memberi seperangkat pertanyaan atau pernyataan tertulis kepada responden untuk dijawabnya (Sugiyono, 2011).

Populasi dalam penelitian ini adalah guru sekolah luar biasa di Jakarta. Prosedur teknik sampling yang digunakan adalah purposive sampling. Teknik pengambilan data pada penelitian ini adalah dengan menggunakan skala psikologis. Skala yang digunakan peneliti dalam variabel empati adalah skala yang diadaptasi dari alat ukur The QCAE (a Questionnaire of Cognitive and Affective Emphaty) yang dibuat oleh Renate L. E. P. Reniers, Rhiannon Corcoran, Richard Drake, Nick M. Shryane, dan Birgit A. Vollm pada tahun 2011. Skala yang digunakan untuk variabel motivasi kerja guru merupakan hasil kontrak berdasarkan literatur jurnal oleh Louis George dan Tara Sabhapathy (2010). 


\section{Hasil Penelitian dan Diskusi}

Dari perhitungan data variabel empati dan kinerja guru diperoleh rata-rata dan nilai simpang baku tiap variabel. Adapun nilai tersebut yaitu: nilai rata-rata empati sebesar 0,82 logit dan nilai rata-rata motivasi kerja guru adalah sebesar 0.61 logit. Nilai standar deviasi empati sebesar 0,73 logit dan nilai standar deviasi motivasi kerja guru sebesar 0.37 logit. Dengan mengetahui nilai mean maka dapat diketahui tingkat empati dan motivasi kerja guru sebagai berikut:

Tabel 1. Kategorisasi Skor Empati

\begin{tabular}{cccc}
\hline Keterangan & Skor & Frekuensi & Persentase \\
\hline Rendah & $\mathrm{X}<0,82$ logit & 39 & 48,1 \\
\hline Tinggi & $\mathrm{X} \geq 0,82$ logit & 42 & 51,9 \\
\hline \multicolumn{5}{c}{ Total } & $\mathbf{8 1}$ & $\mathbf{1 0 0}$ \\
\hline
\end{tabular}

Tabel 2. Kategorisasi Skor Motivasi Kerja Guru

\begin{tabular}{cccc}
\hline Keterangan & Skor & Frekuensi & Persentase \\
\hline Rendah & $X<0,61$ logit & 49 & 60,5 \\
\hline Tinggi & $X \geq 0,61$ logit & 32 & 39,5 \\
\hline & Total & $\mathbf{8 1}$ & $\mathbf{1 0 0}$ \\
\hline
\end{tabular}

Berdasarkan data dari tabel tersebut dapat diketahui bahwa tingkat empati pada penelitian ini memiliki hasil bahwa responden dengan empati tinggi sebesar $51,9 \%$ sedangkan pada kategori empati rendah sebesar $48,1 \%$.

Pada motivasi kerja guru juga dapat diketahui bahwa responden yang memiliki hasil motivasi kerja guru tinggi sebesar 39,5\% sedangkan untuk kategori rendah sebesar $60,5 \%$.

Hasil analisis statistik dengan uji analisis regresi didapatkan hasil yaitu:

Tabel 2. Pengujian Persamaan Regresi

\begin{tabular}{cccc}
\hline & df & F & Sig. \\
\hline Regression & 1 & \multirow{2}{*}{11,272} & 0,001 \\
\hline Residual & 79 & & \\
\hline
\end{tabular}

Berdasarkan hasil pada tabel diatas, maka lebih kecil dari taraf signifikansi 0,05 sehingga dapat diketahui bahwa $\mathrm{F}=11,272 ; \mathrm{p}=0,001<$ 0,05 . Dengan demikian bahwa dapat diketahui bahwa F hitung lebih besar dari F tabel dan nilai $\mathrm{p}$ kerja guru SLB.

Tabel 3. Model Summary

\begin{tabular}{ccccc}
\hline Model & $\mathbf{R}$ & R Square & $\begin{array}{c}\text { Adjusted R } \\
\text { Square }\end{array}$ & $\begin{array}{c}\text { Std. Error of } \\
\text { the Estimate }\end{array}$ \\
\hline 1 & 0,353 & 0,125 & 0,114 & 0,35050 \\
\hline
\end{tabular}

Dan hasil perhitungan dalam tabel tersebut dapat diketahui bahwa nilai perhitungan korelasi ganda $(\mathrm{R})$ yang diperoleh $R$ Square $=0.125=$
$12,5 \%$. Artinya variabel empati memiliki pengaruh pada variabel motivasi kerja guru sebesar 
$12,5 \%$ dan sisanya dipengaruhi oleh faktor lain di luar empati.

Berdasarkan hasil dari penelitian yang dilakukan dengan analisis regresi satu prediktor, maka hasil yang diperoleh adalah terdapat pengaruh yang signifikan antara empati dengan motivasi kerja guru. Hal ini dapat diartikan bahwa empati memiliki pengaruh yang signifikan terhadap motivasi kerja guru sekolah luar biasa.

Dapat diketahui bahwa gambaran mengenai motivasi kerja guru SLB yang berada pada kategori rendah sebanyak 49 responden $(60,5 \%)$ sementara yang berada pada kategori tinggi sebanyak 32 responden (39,5\%). Berdasarkan hasil tersebut dapat dilihat bahwa motivasi kerja guru SLB masih terlihat rendah, hal ini dimungkinkan karena ada faktor-faktor dalam motivasi kerja tersebut yang belum terpenuhi ataupun mencukupi. Menurut Pujiyanti dan Isroah (2013) yang mempengaruhi motivasi seseorang adalah faktor internal dan eksternal. Faktor internal diantaranya adalah ekonomi, prestasi, tanggung jawab dan penghargaan. Sementara untuk faktor eksternal yaitu pembayaran gaji, pemimpin, dan hubungan dengan para pegawai. Menurut peneliti hasil tersebut bisa dimungkinkan dengan melihat data demografi pada tingkat usia, guru SLB yang memiliki rentang usia 51-65 tahun sebanyak 45 guru $(55,6 \%)$ dari 81 guru yang menjadi subjek penelitian. Dari usia tersebut dapat dilihat bahwa subjek penelitian ini sebagian besar berada pada tahap dewasa akhir, menurut peneliti hal ini dapat berpengaruh pada faktor keinginan untuk berprestasi, tantangan dalam bekerja, dan lain sebagainya. Hal ini seperti yang disebutkan dalam Papalia (2014) bahwa pekerja yang lebih tua kecil kemungkinan untuk ditawari atau dengan sukarela untuk melakukan pelatihan, pendidikan, dan memenuhi tantangan pekerjaan seperti itu.

Pada variabel empati kategori rendah sebanyak $39(48,1 \%)$ responden dan pada kategori tinggi sebanyak $42(51,9 \%)$ responden. Menurut Taufik (2012) salah satu yang mempengaruhi empati seseorang adalah gender atau jenis kelamin, hasil penelitian yang dilakukan oleh Ickes, Gesn, \& Graham (2000) dalam buku tersebut menyebutkan bahwa akurasi empati pada perempuan lebih baik dari laki-laki dan temuan tersebut berimplikasi kepada motivasi. Dilihat dari data demografis, jumlah subjek pada penelitian ini lebih banyak subjek berjenis perempuan dibandingkan lakilaki. Subjek perempuan sebanyak 52 guru $(64,2 \%)$ sedangkan laki-laki sebanyak 29 guru $(35,8 \%)$. Hal ini dapat menyebabkan empati pada penelitian ini memiliki kategori tinggi.

Dengan demikian dapat dilihat bahwa sebagian besar motivasi kerja guru SLB berada pada kategori rendah. Jika dilihat dari crosstab kategorisasi skor empati dan motivasi kerja, jumlah responden terbanyak adalah responden dengan tingkat empati dan motivasi kerja guru yang rendah sebanyak 27 responden dan jumlah tersedikit dengan responden dengan empati yang rendah dan memiliki motivasi kerja yang tinggi sebanyak 12 responden.

Berdasarkan uji hipotesis analisis regresi diketahui bahwa $\mathrm{F}$ hitung sebesar 11.272 dengan nilai F tabel sebesar 3.96 ( $d b$ atas $1: 79 d b$ bawah). Hasil tersebut memperlihatkan bahwa F hitung > F tabel, yaitu $11.272>3.96$ atau bisa dengan melihat taraf signifikasi lebih kecil dari nilai $\alpha$ (0.05) yaitu $0.001<0.05$. Dari hasil tersebut maka terlihat bahwa Ho ditolak, yang artinya terdapat pengaruh signifikan antara empati dengan motivasi kerja guru. Pada penelitian ini variabel empati memiliki pengaruh terhadap motivasi kerja guru sebesar $12.5 \%$ sedangkan $87.5 \%$ lainnya dipengaruhi oleh faktor lain yang tidak diteliti dalam penelitian ini. Meskipun empati hanya menyumbang $12.5 \%$ terhadap motivasi kerja guru, tetapi empati tetap dapat dijadikan salah satu faktor yang dapat meningkatkan motivasi kerja guru.

Pengaruh yang dihasilkan oleh variabel empati terhadap motivasi kerja guru adalah positif. Hasil tersebut sesuai dengan kajian teoretik yang menunjukkan bahwa jika seorang guru SLB memiliki empati yang tinggi maka motivasi kerja guru 
tersebut tinggi, sebaliknya jika seorang guru SLB memiliki empati rendah maka motivasi kerja guru tersebut rendah.

Guru SLB yang memiliki motivasi kerja yang tinggi maka guru tersebut dapat dipastikan cenderung memiliki perasaan untuk merasakan apa yang peserta didiknya rasakan dan mudah dalam memahami kondisi peserta didiknya tersebut. Motivasi kerja guru yang tinggi mempengaruhi produktivitas guru dalam mengajar, sehingga guru akan dengan mudah dalam mengajar dan mendidik ABK tanpa mementingkan faktor lain seperti gaji, lingkungan kerja dan lain sebagainya yang berhubungan dengan kondisi dalam mengajar. Dengan demikian dengan motivasi kerja guru yang tinggi dalam mengajar akan menghasilkan kualitas peserta didik yang bermutu baik.

Dari seluruh pembahasan ini maka dapat disimpulkan bawa empati memiliki pengaruh terhadap motivasi guru SLB. Hal ini dapat dijadikan referensi bagi para guru SLB agar motivasi kerja mereka dapat ditingkatkan sehingga mereka dapat mengajar tanpa merasa terbebani dengan ABK dan menghasilkan kualitas pendidikan yang baik.

\section{Kesimpulan}

Penelitian ini mengkaji masalah pengaruh empati terhadap motivasi kerja guru SLB. Berdasarkan hasil penelitian, analisis, dan pembahasan yang telah dilakukan, dapat disimpulkan bahwa terdapat pengaruh yang signifikan antara empati dengan motivasi kerja guru. Pada penelitian ini pengaruh yang dihasilkan bersifat positif, yang artinya semakin tinggi empati seorang guru SLB maka motivasi kerja guru tersebut akan semakin tinggi. Dengan kata lain pada penelitian ini Ho ditolak dan Ha diterima.

\section{Daftar Pustaka}

Asih, G. Y., \& Pratiwi, M. M. (2010). Perilaku Prososial Ditinjau dari Empati dan Kematangan Emosi. Jurnal Psikologi Universitas Muria Kudus, 1(1), 33-42.
Azwar, S. (2015). Penyusunan Skala Psikologi. Yogyakarta: Pustaka Pelajar.

Badriah, L. (2013). Pengaruh Empati dan SelfControl Terhadap Agresivitas Remaja SMA Negeri 3 Kota Tangerang Selatan (Skripsi). Fakultas Psikologi Universitas Islam Negeri Syarif Hidayatullah.

Baron, R, A, \& Byrne. D. (2005). Psikologi Sosial Jilid 2. Jakarta: Erlangga.

Danim, S. (2015). Pengembangan Profesi Guru: dari Pra-Jabatan, Induksi, ke Profesional Madani. Jakarta: Prenadamedia Group.

Departemen Pendidikan Nasional, Pusat Bahasa. (2014). Kamus Bahasa Indonesia. Jakarta: PT Gramedia Pustaka Utama Jakarta.

Djafri, N. (2015). Pengaruh Gaya Kepemimpinan, Empati dan Motivasi Terhadap Budaya Organisasi Studi Kasus Terhadap Kepala Sekolah Dasar Kota Gorontalo. Jurnal Managemen, 19(1), 59- 73.

Fahmi, I. 2014. Perilaku Organisasi Teori, Aplikasi dan Kasus. Bandung: Alfabeta.

Feist, J. \& Feist, G. 2010. Teori Kepribadian: Theories of Personality II. Jakarta: Salemba Humanika.

Firmansyah, I. \& Widuri, E, L. (2014). Subjective Well Being pada Guru Sekolah Luar Biasa. Jurnal Fakultas Psikologi Universitas Ahmad Dahlan, 2(1).

Geoge, L. \& Sabhapathy, T. (2010). Work Motivation of Teachers: Relationship with Transformational and Transactional Leadership Behavior of College Principals. Academic Leadership The Online Journal, 8(2), 1-7.

Hamalik, O. (2008). Proses Belajar mengajar. Jakarta: PT Bumi Aksara. 
Hasibuan, M, S. P. (2010). Organisasi dan Motivasi: Dasar Peningkatan Produktivitas. Jakarta: PT Bumi Aksara.

Hidayat, T., \& Istiadah, N. (2011). Panduan Lengkap Menguasai SPSS 19 untuk Mengolah Data Statistik Penelitian. Jakarta: PT TransMedia.

Istiqomah, D. P. (2015). Dinamika Empati Guru Anak Berkebutuhan Khusus (ABK) di SDLB Putra Jaya Malang (Skripsi). Fakultas Psikologi Universitas Islam Negeri Maulana Malik Ibrahim Malang.

Matutina, D. C. (1993). Manajemen Personalia. Jakarta: PT Rineka Cipta.

Munandar, A, S. (2001). Psikologi Industri dan Organisasi. Jakarta: Penerbit UI.

Muzdalifah, F., \& Listyasari, W. D. (2013). Psikologi Pendidikan 2. Jakarta; Program Studi Psikologi, Universitas Negeri Jakarta.

Myers, D. G. (2012). Psikologi Sosial Jilid 2. Jakarta: Salemba Humanika.

Papalia, D. E., \& Feldman, R. D. (2014). Experience Human Development Menyelami Perkembangan Manusia. Jakarta: Salemba Humanika.

Pujiyanti \& Isroah. (2013). Pengaruh Motivasi Kerja dan Disiplin KerjaTerhadap Kinerja Guru SMA Negeri 1 Ciamis. Kajian Pendidikan Akuntansi Indonesia, 2(1), 184-207.

Purwanto. (2010). Evaluasi Hasil Belajar. Yogyakarta: Pustaka Pelajar.

Rangkuti, A. A. (2013). Statistik Inferensial untuk Penelitian Psikologi dan Pendidikan. Jakarta: FIP Press.

Rangkuti, A. A., \& Wahyuni, L. D. (2016). Modul: Analisis Data Penelitian Kuantitatif Berbasis Classical Test Theory dan Item Response Theory (Rasch Model).
Jakarta: Universitas Negeri Jakarta.

Rangkuti, A. A. (2013). Statistika Parametrik dan Non-Parametrik dalam Bidang Psikologi dan Pendidikan. Jakarta: Program Studi Psikologi Fakultas Ilmu Pendidikan.

Reniers, R. L. E. P., Corcoran, R., Drake, R., Shryane, N. M., \& Völlm, B. A. (2011). The QCAE: a Questionnaire of Cognitive and Affective Emphaty. Journal of Personality Assessment, 93(1), 84-95. doi:10.1080/00223891.2010.528484.

Rohadi. (2008). Pengaruh Manajemen Waktu dan Motivasi Mengajar Terhadap Kompetensi Professional Guru di Sekolah Menengah Atas (SMA). (Thesis). Program Studi Managemen Pendidikan Program Pascasarjana Universitas Negeri Semarang.

Sardiman, A. M. (2008). Interaksi dan Motivasi Belajar Mengajar. Jakarta: PT Raja Grafindo Persada.

Sardiman, A. M. (2010). Interaksi \& Motivasi Belajar Mengajar. Jakarta: PT Raja Grafindo Persada.

Shanty, M. (2012). Strategi Belajar Untuk Anak Berkebutuhan Khusus. Yogyakarta: Familia.

Siagian, S. P. (2004). Manajemen Sumber Daya Manusia. Jakarta: Bumi Aksara.

Slavin, R. E. (2011). Psikologi Pendidikan: Teori dan Praktik Jilid II. Jakarta: PT. Indeks.

Sugiyono. (2011). Metode Penelitian Pendidikan Pendekatan Kuantitatif, Kualitatif dan Research \& Development. Bandung: Alfabeta.

Sumintono, B., \& Widhiarso, W. (2014). Aplikasi Model Rasch untuk Penelitian Ilmu-Ilmu Sosial. Cimahi: Trim Komunikata Publishing House. 
Suryaratri, R. D., \& Rangkuti, A. A. (2013). Statistika Deskriptif dalam Psikologi dan Pendidikan. Jakarta: Universitas Negeri Jakarta.

Syah, M. (2010). Psikologi Pendidikan dengan Pendekatan Baru. Bandung: PT Remaja Rosdakarya.

Taufik. (2012). Empati: Pendekatan Psikologi Sosial. Jakarta : PT Rajawali.
Uno, H. B. (2016). Teori Motivasi dan Pengukurannya: Analisis di Bidang Pendidikan. Jakarta: Bumi Aksara.

Wardhani, D. T. (2012). Burnout di Kalangan Guru Pendidikan Luar Biasa di Kota Bandung. Sekolah Tinggi Kesejahteraan Sosial (STKS) Bandung, 11(1), 73-82.

Winardi. (2001). Motivasi dan Permotivasian dalam Manajemen. Jakarta: PT Raja Grafindo Persada. 